CAEP • Canadian Association of
$\begin{aligned} & \text { Emergency Physicians } \\ & \text { ACMU • Association canadienne } \\ & \text { des médecins d'urgence }\end{aligned}$
WWW.Caep.ca
PrESIDENT / PRÉSIDENT
Andrew W. Affleck, MD, CCFP

Canadian Journal of Emergency Medicine

Journal canadien de la médecine d'urgence

EDITOR-IN-CHIEF / RÉDACTEUR EN CHEF

Grant Innes, MD

University of British Columbia, Vancouver

SEnior Associate Editors / Rédacteurs adjoint

James Ducharme, MD

Dalhousie University, Saint John, NB

Riyad B. Abu-Laban, MD, MHSc

University of British Columbia, Vancouver

MANAGING EdITOR / RÉDACTRICE ADMINISTRATIVE

Penelope Gray-Allan, BA, BSc

ASSOCIATE EDITORS / RÉDACTEURS ASSOCIÉS

EM ADVANCES (original research)

Jacques S. Lee, MD, University of Toronto, Toronto

Ian G. Stiell, MD, MSc, University of Ottawa, Ottawa

Christian Vaillancourt, MD, MSc, University of Ottawa, Ottawa

CJEM Journal Club

Michael J. Bullard, MD, University of Alberta, Edmonton

Eddy S. Lang, MD CM, McGill University, Montréal

CASE REPORTS

Anthony S. Taylor, MD, University of Calgary, Calgary

Community EM

David Mann, MD, Powell River General Hospital, Powell River, BC

Methodology: the Science of EM

Andrew Worster, MD, MSc, McMaster University, Hamilton, Ont.

PHARMACOTHERAPY

Peter J. Zed, BSc(Pharm), PharmD, University of British Columbia, Vancouver

Jeff Eppler, MD, Kelowna General Hospital, Kelowna, BC

ED ADMINISTRATION

Christopher M.B. Fernandes, MD, McMaster University,

Hamilton, Ont.

Marc Afilalo, MD, McGill University, Montréal

EDUCATION

Jason R. Frank, MD, MA (Ed), University of Ottawa, Ottawa

STATE OF THE ART (review articles and topical updates)

Jeffrey R. Brubacher, MD, University of British Columbia,

Vancouver

Toxicology

Roy Purssell, MD, University of British Columbia, Vancouver

CONTROVERSIES (issues and commentaries)

Jeffrey Freeman, MD, University of Michigan, Ann Arbor, Mich.

Pediatric EM

Lance Brown, MD, Loma Linda University Medical Center and Children's Hospital, Loma Linda, Calif.

Ran Goldman, MD, Hospital for Sick Children, Toronto

Niranjan Kissoon, MD, University of Florida HSC/Jacksonville, Jacksonville, Fla.

\section{HuMOUR AND HUMANITY}

Jeffrey Freeman, MD, University of Michigan, Ann Arbor, Mich.

Diagnostic Challenge

Joseph Finkler, MSc, MD, University of British Columbia, Vancouver

INTERNATIONAL EM

Garth Dickinson, MD, Christ Church, Barbados

Medical Mythology

Mel Herbert, MD, University of Southern California, Los Angeles

RESIDENT Issues

Shelby Haque, MD, University of Alberta, Edmonton

Aaron Sibley, MD, University of Alberta, Edmonton
CJEM

Journal canadien de la médecine d'urgence

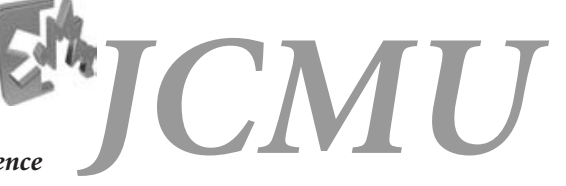

\title{
TABLE OF CONTENTS • TABLE DES MatiÈRES
}

\section{ORIGINAL RESEARCH • RECHERCHE ORIGINALE}

\section{ADVANCES}

Emergency department use by CTAS Levels IV and V patients

S. Field, A. Lantz

\section{ADVANCES}

Effect of the SARS outbreak on visits to a community hospital emergency department

M. Heiber, W.Y.W. Lou

\section{EDUCATION・ÉDUCATION}

\section{State of the ART}

Systematic review of randomized controlled trials of therapeutic hypothermia as a neuroprotectant in post cardiac arrest patients K.W. Cheung, R.S. Green, K.D. Magee

\section{StATE OF the ART}

Hyperglycemia in acutely ill emergency patients - Cause or effect?

W.R. Henderson, D.R. Chittock, V.K. Dhingra, J.J. Ronco

\section{Diagnostic Challenge}

Acute ischemic upper limb in a young man:

an emergency presentation; Answer

L. Jones, A. Birnie, U. Shanker

$345 ; 370$

\section{COMMENTARIES • COMMENTAIRES}

\section{Controversies}

Etomidate for rapid sequence intubation in the emergency department: Is adrenal suppression a concern?

P.J. Zed, V.H. Mabasa, R.S. Slavik, R.B. Abu-Laban

\section{Controversies}

You need tube, me give one amp of etomidate and SUX

M.L.A. Sivilotti

\section{CASE REPORTS • OBSERVATIONS DE CAS}

Posterior sternoclavicular joint dislocation: case report and discussion N. Kuzak, A. Ishkanian, R.B. Abu-Laban 
EDITORS AT LARGE / RÉDACTEURS OCCASIONNELS

Tim Allen, MD, Quebec City

Greta Cummings, BScN, MEd, RN, PhD, Edmonton

Brian Goldman, MD, Toronto

Daniel W. Howes, MD, Kingston, Ont.

Shane Neilson, BSc, MD, Halifax

Michael J. Schull, MD, MSc, Toronto

Marco Sivilotti, MD, MSc, Kingston, Ont.

Andrew H. Travers, BSc, MD, MSc (Epidemiol), Halifax

$\underline{\text { Web SITE }}$

Vacant

Business And Promotion

Chris Evans, MD
University of Alberta, Edmonton cevans@ualberta.ca

Translation / Traduction

Danielle Séguin-Tétreault, MTrad

Marketing and Advertising Sales / Marketing et Publicité

Keith Comunications Inc. info@keithhealthcare.com

Toronto: 905 278-6700 or 800 661-5004; fax 905 278-4850

Montréal: 514 624-6979 or 877 761-0447; fax 514 624-6707

CJEM is owned by the Canadian Association of Emergency Physicians

(CAEP) and printed by Dollco Printing, Ottawa

CAEP Head Office: 1785 Alta Vista Dr., Ste. 104, Ottawa ON K1G 3Y6; tel 613 523-3343; fax 613 523-0190; cjem@ caep.ca

Editorial inquiries, submissions and all other correspondence: CJEM, c/o Dr. Grant Innes, Dept. of Emergency Medicine, St. Paul's Hospital, 1081 Burrard St., Vancouver BC V6Z 1Y6; 604 806-8980, fax 604 608-9810, cjem@caep.ca

Instructions for Authors, Service Information: see Table of Contents. Address changes or requests for permission to reproduce items in CJEM: contact cjemsubscriptions@caep.ca

Publications mail agreement no. 0344505499. USPS \#017-766; periodical postage paid at Champlain, NY. Return undeliverable copies to the CAEP Head Office or to IMS of NY, 100 Walnut St. \#1, PO Box 1518 Champlain NY 12919-1518. ISSN 1481-8035.

We acknowledge the financial support of the Government of Canada, through the Canada Magazine Fund, toward our editorial costs.

\section{PAAB* Canadä}

All prescription drug advertisements have been cleared by the Pharmaceutical Advertising Advisory Board.

(C) 2006 Canadian Association of Emergency Physicians

Association canadienne des médecins d'urgence

CMA Media Inc. - Publisher / AMC Média Inc. - Éditeur

CJEM is published in January, March, May, July, September and November for CAEP by CMA Media Inc., Ottawa. CAEP, the Canadian Medical Association (CMA) and CMA Media Inc. assume no responsibility or liability for damages arising from any error or omission, or from the use of any information or advice contained in the journal, including articles, editorials, case reports, reviews, media reviews, letters and advertisements. All editorial matter in CJEM represents the opinions of the authors and not necessarily those of CAEP, the CMA or CMA Media Inc.

PRESIDENT / PRÉSIDENT

Graham Morris

DIRECTOR / DIRECTRICE

Glenda Proctor, MSc, ELS

EDITOR / RÉDACTRICE

Jennifer E. Raiche

800 663-7336 x2114; fax 613 565-2382; jennifer.raiche@cma.ca PRODUCTION

Kathryn A. Freamo

Nicole Barbeau, Clara Walker

Classified Advertising / ANNONCES Classées

Beverley Kirkpatrick, Deborah Rodd

613 731-8610 x2127/2314; fax 613 565-7488; advertising@cma.ca

DisPLAy ADVERTISING / ANNONCES PUBLICITAIRES

Nancy Pope, 613 731-8610 x2111
Bowel perforation after single-dose activated charcoal

J.P. Green, W. McCauley

358

Lamotrigine as a possible cause of QRS prolongation in a patient with known seizure disorder

T.J.S. Herold

Primary amebic meningoencephalitis: a silent killer

I. Grate, Jr.

LETTERS

315

Clarification - "Pretreatment" in RSI, S. Campbell, G. Kovacs,

K. MacQuarrie, and the AIME Instructors. AMI after epinephrine,

G. Maddison; A. Shah. Erratum.

CAEP 2007 CALl for Abstracts

ACMU 2007 - DEMANDE DE COMMUNICATIONS

CAEP RESEARCH GRANTS 2007

346

AEM CALL FOR PAPERS

354

Calendar • Calendrier

372

BOURSES DE RECHERCHE DE L'ACMU 2007

373

Classified Advertising • Annonces Classées

INSTRUCTIONS FOR AUTHORS • INSTRUCTIONS POUR LES AUTEURS

Visit / visitez www.caep.ca

SERVice Information • Services

Visit / visitez www.caep.ca

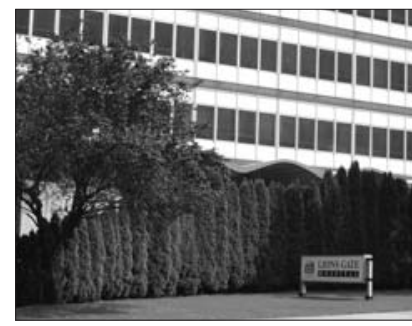

About the Cover:

Lions Gate Hospital

North Vancouver, BC

Lions Gate is one of 14 hospitals in the

Vancouver Coastal Health Authority.

A recognized trauma centre, Lions Gate

has 335 beds and 7 operating rooms.

It is the 4th busiest hospital in Vancouver

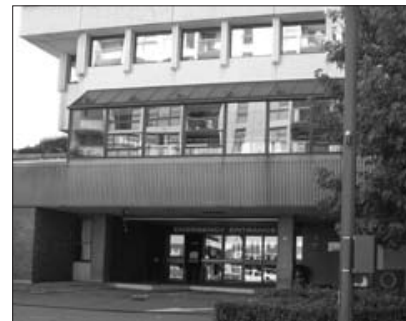
and 1 of only 5 neurosurgery centres in British Columbia.

Photos by: Penelope Gray-Allan 